\title{
Performances of Legume-grass Mixtures under Different Cutting Managements in Mediterranean Environments
}

\author{
Anna Iannucci ${ }^{1 *}$, Antonio Melchiorre Carroni ${ }^{2}$, Pasquale Martiniello ${ }^{1}$ \\ ${ }^{1}$ Istituto Sperimentale Colture Foraggere, SOP di Foggia \\ Via Napoli 52, 71100 Foggia, Italy \\ ${ }^{2}$ Istituto Sperimentale Colture Foraggere, SOP di Cagliari \\ Via Crespellani 4, 09121 Cagliari, Italy
}

Received: 15 December 2004. Accepted: 17 March 2006

\begin{abstract}
Annual forage crops have great importance for sustaining animal production in southern Italy. Knowledge of the performance of legume-grass associations under management similar to systems encountered in farm practice is essential for their effective exploitation of the available environmental resources. The purpose of this investigation was to estimate the effects of five cutting managements on the productivity and botanical composition of ten annual fodder crop mixtures in two Mediterranean environments. Ten ternary combinations of one grass (Avena sativa L., oat and Lolium multiflorum Lam., Italian ryegrass), one clover (Trifolium alexandrinum L., berseem; Trifolium incarnatum L., crimson and Trifolium squarrosum L., squarrosum) or burr medic (Medicago polymorpha L.) and common vetch (Vicia sativa L.) were compared in a field trial (split-plot design, 3 replicates) in two locations (Cagliari and Foggia, Italy) during the 2000-2001 growing season. The cutting treatments included a winter grazing simulation $(\mathrm{G})$, a cutting only regime at early (EF) or late flowering (F) of legumes and a combination of treatments (GEF and GF). Plant density (no. $\left.\mathrm{m}^{-2}\right)$ prior to cutting, dry matter yield $\left(\mathrm{g} \mathrm{m}^{-2}\right)$ and botanical composition (\%) were evaluated. Considerable differences were observed in the harvestable dry matter yields of mixtures among cutting treatments in both localities, with treatment $\mathrm{F}$ showing the higher values $\left(787.1\right.$ and $415.7 \mathrm{~g} \mathrm{~m}^{-2}$ for Cagliari and Foggia, respectively). The forage species were able to compete and establish good growth during their initial phase in both localities. However, the botanical composition between the two sites differed considerably after the winter period. Particularly, at Foggia, grass dominance was a permanent feature of all treatments, and all the mixtures contained about $84 \%$ of grass. Italian ryegrass was the most representative species under all treatments in both sites. Mixtures with Italian ryegrass, crimson or berseem clovers and vetch showed higher adaptability to cutting treatments particularly at Cagliari. Our results showed that the forage species associations studied can be grown successfully under simulated grazing treatment during the winter season and under the double land-use system (integrated grazing and cutting) adopted at Cagliari. These treatments provide a reasonably economical means of assessing mixtures under diverse farming conditions. However, as a fraction of the plant population in swards of this experiment diminished over time, particularly at one site, the optimum of species present in these forage species associations have yet to be determined.
\end{abstract}

Key-words: legume-grass mixtures, cutting management, dry matter yield, botanical composition.

\section{Introduction}

In the Mediterranean environment the chief limiting factor to productivity is the concentration of rainfall during the cold winter season and its total absence during the hot summer with a high intra and inter annual variability. As reported by Blondel and Aronson (1999) and by
Del Pozo and Aronson (2000), annual plants occur widely in the Mediterranean Basin where they often constitute half the regional vegetation, whereas they rarely amount to more than one-tenth in other parts of the world, despite the fact that annuals have cope with highly seasonal environments and a considerable degree

\footnotetext{
* Corresponding Author: Tel.: +39 0881 741632; Fax: +39 0881 741632. E-mail address: iscf.fg@isnet.it
} 
of climatic unpredictability. As consequence, grasslands consist of mainly annual grasses and legumes, most of which escape over summer as seed (Sitzia et al., 2000).

Annual forage crops with autumn-spring cycles are the most interesting for a sustainable production and commonly grown crops in the regions of southern Italy; they cover a relatively small area but constitute the most productive part of forage resources. They are mainly used for the production of hay or silage and only complementarily for grazing (Papanastasis and Mansat, 1996). Furthermore, among the different types of use, the legume-grass association is the cropping system able to achieve the highest forage biomass yield under the weather conditions of Mediterranean environments (Caballero, 1993). Mixtures used for haying generally consist of two or three species, one grass and two legumes that are very important in stabilizing herbage production over the years and in yielding a more balanced forage composition (Corleto, 1988).

Grass is essential in a mixture for high yields and dense swards, but the benefit of including legumes in mixtures with grasses has long been recognised: legumes generally have higher palatability, forage digestibility, protein concentration, and better quality than other forages. Furthermore, legume-grass mixtures produce more forage than pure stands of grasses receiving no or moderate amounts of $\mathrm{N}$ fertiliser (Barnett and Posler, 1983; Dobson et al., 1976; Jones et al., 1988). As reported by Kessler and Lehmann (1998), in order to combine the advantages of both legumes and grasses, mixed swards should be 30 to $50 \%$ composed by legumes and $50 \%$ to $70 \%$ by grasses. However, herbage yields and quality of legume-grass mixtures often decline with time because of the loss of legume plants (McBratney, 1981, 1984; Sheaffer et al., 1984). Furthermore, because the growth conditions and sward productivity depend on climate, soil properties, topography and farm-specific utilization, a wide spectrum of different mixtures is required. Hence, the possibility to obtain quantitatively and qualitatively profitable yields depends on the choice of botanical components and variety in addition to the seed rate (Evans et al., 1990).

At present, Italian farmers can evaluate the potential of individual species and varieties by using the National List of fodder crops which is based largely on small-plot trials managed under one cut of forage made at heading or flowering. There is no information available about the potential yield of mixtures and the contribution made by single fodder species to a mixture. Since annual grass and legume forage crops are used both for hay and grazing, it is important that the yield potential of each variety is assessed by an evaluating procedure which simulates as closely as possible the one practised on farms. Furthermore, the interaction between forage species and cutting management emphasizes the need to use suitable comparison techniques (i.e. two contrasting frequencies of cutting, forage harvest and simulated grazing).

For a more realistic evaluation of productive potential of annual fodder crops in association, an experiment was designed to assess the effects of the cutting regimes on dry matter yield and botanical composition of ten legume-grass mixtures grown at two localities in southern Italy.

\section{Materials and methods}

Two field experiments were carried out during the 2000-2001 growing season at the Forage Crop Institute of Cagliari $\left(9^{\circ} 38^{\prime} \mathrm{W}, 39^{\circ} 29^{\prime} \mathrm{N} ; 68\right.$ $\mathrm{m}$ above sea level) and Foggia $\left(15^{\circ} 33^{\prime} \mathrm{E}\right.$, $41^{\circ} 31^{\prime} \mathrm{N}$; $76 \mathrm{~m}$ above sea level), both located in southern Italy, using annual populations, ecotypes and cultivars of clovers: berseem (Trifolium alexandrinum L., cv. "Sacromonte"), crimson ( $T$. incarnatum L., population "Ungherese" and population "USA") and squarrosum (T. squarrosum L., population "Commerciale"); burr medic (Medicago polymorpha L., cv. "Anglona"); common vetch (Vicia sativa L., cv. "Catarina" and cv. "Mirabella") and graminaceous species: oat (Avena sativa L., cv. "Argentina" and cv. "Tropicale") and Italian ryegrass (Lolium multiflorum Lam., cv. "Asso"). At Cagliari the trial was established on a sandy clay loam soil (USDA classification) with the following characteristics: clay $28 \%$, silt $26 \%$, sand $46 \%, \mathrm{pH} 8$ (in $\mathrm{H}_{2} \mathrm{O}$ ), available $\mathrm{P} 33 \mathrm{mg} \mathrm{kg}^{-1}$ (Olsen method), exchangeable $\mathrm{K} 311 \mathrm{mg} \mathrm{kg}^{-1}$ $\left(\mathrm{NH}_{4} \mathrm{Ac}\right.$ ), organic matter $21 \mathrm{~g} \mathrm{~kg}^{-1}$ (WalkeyBlack method). The soil at Foggia is a loam soil (USDA classification) with the following characteristics: clay $21 \%$, silt $43 \%$, sand $36 \%$, pH 8 
Table 1. Details of the fodder crop mixtures to three components.

\begin{tabular}{|c|c|c|c|c|c|}
\hline Mixture & Species & Genotype & $\begin{array}{l}\text { Mean flowering } \\
\text { or heading date } \\
\text { (day of year) }\end{array}$ & $\begin{array}{l}\text { Mixture } \\
\text { seed rate } \\
\left(\mathrm{kg} \mathrm{ha}^{-1}\right)\end{array}$ & $\begin{array}{c}\text { Ratio } \\
(\%)\end{array}$ \\
\hline 1 & $\begin{array}{l}\text { Avena sativa } \mathrm{L} . \\
\text { Trifolium incarnatum } \mathrm{L} . \\
\text { Vicia sativa } \mathrm{L} .\end{array}$ & $\begin{array}{l}\text { cv. Argentina }{ }^{\dagger} \\
\text { pop. USA } \\
\text { cv. Mirabella }\end{array}$ & $\begin{array}{l}127 \\
133 \\
120\end{array}$ & 120 & $\begin{array}{l}30 \\
20 \\
50\end{array}$ \\
\hline 2 & $\begin{array}{l}\text { Lolium multiflorum Lam. } \\
\text { Trifolium incarnatum L. } \\
\text { Vicia sativa } \mathrm{L} .\end{array}$ & $\begin{array}{l}\text { cv. Asso } \\
\text { pop. USA } \\
\text { cv. Mirabella }\end{array}$ & $\begin{array}{l}134 \\
133 \\
120\end{array}$ & 100 & $\begin{array}{l}30 \\
20 \\
50\end{array}$ \\
\hline 3 & $\begin{array}{l}\text { Avena sativa } \mathrm{L} . \\
\text { Trifolium incarnatum } \mathrm{L} . \\
\text { Vicia sativa } \mathrm{L} .\end{array}$ & $\begin{array}{l}\text { cv. Tropicale } \\
\text { pop. Ungherese } \\
\text { cv. Catarina }\end{array}$ & $\begin{array}{l}135 \\
130 \\
140\end{array}$ & 120 & $\begin{array}{l}30 \\
20 \\
50\end{array}$ \\
\hline 4 & $\begin{array}{l}\text { Lolium multiflorum Lam. } \\
\text { Trifolium incarnatum L. } \\
\text { Vicia sativa } \mathrm{L} .\end{array}$ & $\begin{array}{l}\text { cv. Asso } \\
\text { pop. Ungherese } \\
\text { cv. Catarina }\end{array}$ & $\begin{array}{l}134 \\
130 \\
140\end{array}$ & 100 & $\begin{array}{l}30 \\
20 \\
50\end{array}$ \\
\hline 5 & $\begin{array}{l}\text { Avena sativa } \mathrm{L} . \\
\text { Trifolium squarrosum } \mathrm{L} \text {. } \\
\text { Vicia sativa } \mathrm{L} .\end{array}$ & $\begin{array}{l}\text { cv. Tropicale } \\
\text { pop. commerciale } \\
\text { cv. Catarina }\end{array}$ & $\begin{array}{l}135 \\
144 \\
140\end{array}$ & 120 & $\begin{array}{l}30 \\
20 \\
50\end{array}$ \\
\hline 6 & $\begin{array}{l}\text { Lolium multiflorum Lam. } \\
\text { Trifolium squarrosum L. } \\
\text { Vicia sativa L. }\end{array}$ & $\begin{array}{l}\text { cv. Asso } \\
\text { pop. commerciale } \\
\text { cv. Catarina }\end{array}$ & $\begin{array}{l}134 \\
144 \\
140\end{array}$ & 100 & $\begin{array}{l}30 \\
20 \\
50\end{array}$ \\
\hline 7 & $\begin{array}{l}\text { Avena sativa } \mathrm{L} . \\
\text { Trifolium alexandrinum } \mathrm{L} . \\
\text { Vicia sativa } \mathrm{L} .\end{array}$ & $\begin{array}{l}\text { cv. Tropicale } \\
\text { cv. Sacromonte } \\
\text { cv. Catarina }\end{array}$ & $\begin{array}{l}135 \\
147 \\
140\end{array}$ & 120 & $\begin{array}{l}30 \\
20 \\
50\end{array}$ \\
\hline 8 & $\begin{array}{l}\text { Lolium multiflorum Lam. } \\
\text { Trifolium alexandrinum L. } \\
\text { Vicia sativa } \mathrm{L} .\end{array}$ & $\begin{array}{l}\text { cv. Asso } \\
\text { cv. Sacromonte } \\
\text { cv. Catarina }\end{array}$ & $\begin{array}{l}134 \\
147 \\
140\end{array}$ & 100 & $\begin{array}{l}30 \\
20 \\
50\end{array}$ \\
\hline 9 & $\begin{array}{l}\text { Avena sativa } \mathrm{L} . \\
\text { Medicago polymorpha } \mathrm{L} \text {. } \\
\text { Vicia sativa } \mathrm{L} .\end{array}$ & $\begin{array}{l}\text { cv. Argentina } \\
\text { cv. Anglona } \\
\text { cv. Mirabella }\end{array}$ & $\begin{array}{l}127 \\
118 \\
120\end{array}$ & 120 & $\begin{array}{l}30 \\
20 \\
50\end{array}$ \\
\hline 10 & $\begin{array}{l}\text { Lolium multiflorum Lam. } \\
\text { Medicago polymorpha L. } \\
\text { Vicia sativa } \mathrm{L} .\end{array}$ & $\begin{array}{l}\text { cv. Asso } \\
\text { cv. Anglona } \\
\text { cv. Mirabella }\end{array}$ & $\begin{array}{l}134 \\
118 \\
120\end{array}$ & 100 & $\begin{array}{l}30 \\
20 \\
50\end{array}$ \\
\hline
\end{tabular}

${ }^{\dagger} \mathrm{cv} .=$ cultivar; ec. $=$ ecotype; pop. $=$ population.

(in $\mathrm{H}_{2} \mathrm{O}$ ), available $\mathrm{P} 15 \mathrm{mg} \mathrm{kg}$ (Olsen method), exchangeable $\mathrm{K} 800 \mathrm{mg} \mathrm{kg}^{-1}\left(\mathrm{NH}_{4} \mathrm{Ac}\right)$, organic matter $21 \mathrm{~g} \mathrm{~kg}^{-1}$ (Walkey-Black method). The forage species were grown in mixtures containing one grass and two legumes; the details of botanical composition, genotype, mean flowering or heading date, mixture seed rate and ratio of each component are shown in Table 1. The experiments were established at the beginning of November (05/11/2000) and December (07/12/2000) at Foggia and Cagliari, respectively. Plot size was $6 \mathrm{~m}^{2}(2 \mathrm{~m}$ long by $3 \mathrm{~m}$ wide) and consisted of ten rows about $20 \mathrm{~cm}$ apart. The mixtures were sown in alternate rows with the same row spacing by hand. To avoid possible confounding results of residual effects of the previous year's treatments, each experi- ment was established on an area previously cropped with tall fescue (Festuca arundinacea Schreb.) and durum wheat (Triticum durum Desf.) at Cagliari and Foggia, respectively. In both trials, a chemical fertilizer $\left(32 \mathrm{~kg} \mathrm{ha}^{-1}\right.$ of nitrogen as ammonia and $70 \mathrm{~kg} \mathrm{ha}^{-1}$ of $\mathrm{P}_{2} \mathrm{O}_{5}$ as triple superphosphate) was applied prior to sowing. Nitrogen fertilization was repeated in early March at the rate of $100 \mathrm{~kg} \mathrm{ha}^{-1}$. Monthly mean of minimum and maximum temperatures and precipitation data collected during the trial at each research site are reported in Table 2 .

The cutting management involved five treatments: two cuts simulating grazing during the winter when the crop was about $10 \mathrm{~cm}$ high $(\mathrm{G})$, one cut for forage when $10 \%$ of the clover or burr medic stems were at the flowering stage 
Table 2. Weather data (monthly means) during the course of the experiment in 2000 and 2001, and the long-term average (1979-1999) for each parameter at Cagliari and Foggia.

\begin{tabular}{|c|c|c|c|c|c|c|c|c|c|}
\hline & October & November & December & January & February & March & April & May & Total \\
\hline \multicolumn{10}{|c|}{ Minimum temperature $\left({ }^{\circ} \mathrm{C}\right)$} \\
\hline Cagliari (CA) & 16.1 & 15.2 & 10.0 & 7.4 & 6.4 & 8.8 & 10.7 & 14.8 & - \\
\hline Foggia (FG) & 12.5 & 9.0 & 5.8 & 6.1 & 3.6 & 10.2 & 7.0 & 12.5 & - \\
\hline 20-year average CA & 14.1 & 9.9 & 6.9 & 5.8 & 5.6 & 7.4 & 8.9 & 12.1 & - \\
\hline 20-year average FG & 13.0 & 8.5 & 5.4 & 3.9 & 3.3 & 5.1 & 7.6 & 12.1 & - \\
\hline \multicolumn{10}{|c|}{ Maximum temperature $\left({ }^{\circ} \mathrm{C}\right)$} \\
\hline Cagliari (CA) & 25.5 & 25.2 & 18.3 & 15.7 & 13.8 & 17.4 & 18.2 & 26.6 & - \\
\hline Foggia $(\mathrm{FG})$ & 23.0 & 17.5 & 14.9 & 13.5 & 13.5 & 20.6 & 18.6 & 25.9 & - \\
\hline 20-year average CA & 25.3 & 18.8 & 14.6 & 13.8 & 14.3 & 16.8 & 19.1 & 23.3 & - \\
\hline 20-year average FG & 23.5 & 16.8 & 13.3 & 12.3 & 12.9 & 16.3 & 19.9 & 25.6 & - \\
\hline \multicolumn{10}{|l|}{ Rainfall (mm) } \\
\hline Cagliari (CA) & 87.6 & 101.2 & 87.2 & 69.4 & 35.0 & 22.4 & 22.8 & 33.2 & 458.8 \\
\hline Foggia (FG) & 12.3 & 32.4 & 25.0 & 96.7 & 16.4 & 9.8 & 63.7 & 15.4 & 271.7 \\
\hline 20-year average CA & 42.4 & 43.9 & 28.1 & 35.4 & 36.4 & 38.7 & 36.0 & 26.4 & 287.3 \\
\hline 20-year average FG & 40.4 & 66.1 & 38.0 & 39.7 & 39.6 & 37.2 & 33.3 & 36.6 & 330.9 \\
\hline
\end{tabular}

(EF), one cut for forage when $100 \%$ of the clover or burr medic stems were at the flowering stage $(\mathrm{F})$, as $\mathrm{G}$ and one regrowth cut applied according to EF (GEF), and as $G$ and one regrowth cut applied according to $F(G F)$. These last two treatments were only carried out at Cagliari trial. Each mixture was individually harvested at the established physiological stage, except under treatment $G$ when all plots were cut at the same time. The traits assessed were the number of plants per $\mathrm{m}^{2}$ before cuts of the first treatment $(G)$ were applied, herbage dry matter yield $\left(\mathrm{g} \mathrm{m}^{-2}\right)$ and the proportion of botanical component (on dry matter basis). Herbage was cut by a plot harvester at about 5 $\mathrm{cm}$ from ground level. A $1 \mathrm{~m}^{2}$ subsample was previously taken from the centre of the plot at each harvest to determine dry matter content and for manual separation into grass, clover or burr medic and vetch. Dry matter content was determined from fresh samples dried at $60{ }^{\circ} \mathrm{C}$ with forced ventilation for $72 \mathrm{~h}$. For treatment $\mathrm{G}$ the total dry matter yield was reported as a total over two cuts.

The experimental design was a split-plot with three randomized complete blocks. The main plot was a cutting management and mixture as subplots. The ANOVA used a mixed model, with localities and replications as random effects and cutting managements and mixtures as fixed effects. The effects of locality, mixture and cutting management and their interac- tions were tested with the appropriate error terms. Locality $\mathrm{x}$ cutting treatment interaction occurred for most the traits, so data from each treatment were analysed separately. Separation of means was conducted using the LSD test when the $F$ test was statistically significant at $P$ $\leq 0.05$. The arcsin transformation was made on percent data before analysis; back-transformed means are presented. A regression equation was developed to measure the contribution made by grass to total dry matter yield and to compare proportions of legume and grass components under different cutting treatments.

\section{Results}

Weather conditions during growth had different effects on the development of legumes in association with graminaceous species. As shown in Table 2, lower temperatures, particularly during winter months (average minimum temperature from November to February was $6.1^{\circ} \mathrm{C}$ and 9.8 ${ }^{\circ} \mathrm{C}$ for Foggia and Cagliari, respectively) and drier weather (except in January and April) were recorded at Foggia compared with Cagliari.

There was no difference between the two localities in the plant density of each component recorded prior to cutting (13/12/2001 and 15/01/2001 at Cagliari and Foggia, respectively), however the mixtures were statistically different (Table 3). In particular, mixtures 6 and 8 (with 
Table 3. Plant density $\left(\mathrm{n} \mathrm{m}^{-2}\right)$ before the cuttings for ten mixtures in two localities.

\begin{tabular}{|c|c|c|c|c|c|}
\hline & \multirow{2}{*}{$\begin{array}{l}\text { Botanical } \\
\text { composition }^{\dagger}\end{array}$} & \multicolumn{4}{|c|}{ Plant density } \\
\hline & & Grass & $\begin{array}{l}\text { Clover or } \\
\text { burr medic }\end{array}$ & Vetch & Total \\
\hline \multicolumn{6}{|l|}{ Mixture (M) } \\
\hline 1 & $\mathrm{As}+\mathrm{Ti}+\mathrm{Vs}$ & $82.7 \mathrm{c}$ & $292.8 \mathrm{bc}$ & $107.8 \mathrm{a}$ & $483.3 \mathrm{de}$ \\
\hline 2 & $\mathrm{Lm}+\mathrm{Ti}+\mathrm{Vs}$ & $477.7 \mathrm{~b}$ & $226.7 \mathrm{c}$ & $73.5 \mathrm{bc}$ & $777.8 \mathrm{~b}$ \\
\hline 3 & $\mathrm{As}+\mathrm{Ti}+\mathrm{Vs}$ & $95.7 \mathrm{c}$ & $329.2 \mathrm{ab}$ & $111.2 \mathrm{a}$ & $536.0 \mathrm{cde}$ \\
\hline 4 & $\mathrm{Lm}+\mathrm{Ti}+\mathrm{Vs}$ & $547.3 \mathrm{ab}$ & $345.7 \mathrm{ab}$ & $94.0 \mathrm{ab}$ & $987.0 \mathrm{a}$ \\
\hline 5 & $\mathrm{As}+\mathrm{Ts}+\mathrm{Vs}$ & $164.8 \mathrm{c}$ & $335.3 \mathrm{ab}$ & $108.8 \mathrm{a}$ & $609.0 \mathrm{c}$ \\
\hline 6 & $\mathrm{Lm}+\mathrm{Ts}+\mathrm{Vs}$ & $608.5 \mathrm{a}$ & $320.3 \mathrm{abc}$ & $71.5 \mathrm{bc}$ & $1000.3 \mathrm{a}$ \\
\hline 7 & $\mathrm{As}+\mathrm{Ta}+\mathrm{Vs}$ & $101.2 \mathrm{c}$ & 389.8 a & $99.0 \mathrm{a}$ & $590.0 \mathrm{~cd}$ \\
\hline 8 & $\mathrm{Lm}+\mathrm{Ta}+\mathrm{Vs}$ & $573.0 \mathrm{ab}$ & $398.2 \mathrm{a}$ & $62.5 \mathrm{c}$ & 1033.7 a \\
\hline 9 & $\mathrm{As}+\mathrm{Mp}+\mathrm{Vs}$ & $83.0 \mathrm{c}$ & $282.3 \mathrm{bc}$ & $89.8 \mathrm{ab}$ & $455.2 \mathrm{e}$ \\
\hline 10 & $\mathrm{Lm}+\mathrm{Mp}+\mathrm{Vs}$ & $504.3 \mathrm{ab}$ & $280.5 \mathrm{bc}$ & $73.7 \mathrm{bc}$ & $858.5 \mathrm{~b}$ \\
\hline \multicolumn{6}{|l|}{$\operatorname{LSD}_{(P \leq 0.05)}$} \\
\hline Locality (L) & & NS & NS & NS & NS \\
\hline Mixture (M) & & 118.9 & 95.4 & 24.7 & 118.9 \\
\hline $\mathrm{L} \times \mathrm{M}$ & & NS & NS & NS & NS \\
\hline
\end{tabular}

${ }^{\dagger} \mathrm{As}=$ Avena sativa $; \mathrm{Lm}=$ Lolium multiflorum $; \mathrm{Ta}=$ Trifolium alexandrinum $; \mathrm{Ti}=$ Trifolium incarnatum $; \mathrm{Ts}=$ Trifolium squarrosum $; \mathrm{Mp}=$ Medicago polymorpha $; \mathrm{Vs}=$ Vicia sativa .

Values within a column not followed by the same letter are significantly different at $P \leq 0.05$.

Italian ryegrass as grass component) showed the highest number of plants per $\mathrm{m}^{2}(1000$ and 1034 , respectively), while 1 and 9 (with oat as grass component) the lesser ones (483 and 455, respectively).

There was a significant difference in total dry matter yield between localities with Foggia showing higher values under $\mathrm{G}$ treatment only (Tables 4 and 5). Mean dry matter yields were significantly affected by tha cutting managements at both sites, the higher values were achieved in spring under $F$ treatment (787.1 and $415.7 \mathrm{~g} \mathrm{~m}^{-2}$ for Cagliari and Foggia, respectively); whereas production under treatments GEF and GF decreased to 282.3 and $372.1 \mathrm{~g} \mathrm{~m}^{-2}$ at Cagliari (Table 5). There were significant dif- ferences among the mixtures for dry matter yield. In paricular, mixture 2 showed the highest mean value at Cagliari $\left(541 \mathrm{~g} \mathrm{~m}^{-2}\right)$ and mixtures 8 and 10 were the most productive at Foggia (431.3 and $418.8 \mathrm{~g} \mathrm{~m}^{-2}$, respectively).

As shown in Table 6, botanical composition was greatly affected by the cutting treatment.

In both localities and under all cutting treatments, Italian ryegrass was the most representative of the grass species. At Cagliari, under treatments EF and F, clovers or burr medic contributed very little (about 6\%) to mixture production. Furthermore, clovers tended to increase from hay utilization treatments to those with winter simulated grazing (about $23 \%$ of average G, GEF and GF). The vetch showed, as

Table 4. ANOVA F test results for total dry matter yield $\left(\mathrm{g} \mathrm{m}^{-2}\right)$ of ten mixtures in two localities under different cutting managements.

\begin{tabular}{lcccccc}
\hline & \multicolumn{5}{c}{ Cutting management $^{\dagger}$} \\
\cline { 2 - 7 } & df & G & EF & F & GEF & GF \\
\hline Locality (L) & 1 & $* *$ & $*$ & $*$ & - & - \\
Mixture (M) & 9 & $*$ & NS & NS & $*$ & NS \\
L x M & 9 & NS & $* *$ & NS & - & - \\
\hline
\end{tabular}

Cutting management: $\mathrm{G}=$ two simulated grazings; $\mathrm{EF}=$ one cut at early flowering; $\mathrm{F}=$ one cut at full bloom; $\mathrm{GEF}=$ as $\mathrm{G}$ and regrowth cut as in EF; GF = as $\mathrm{G}$ and regrowth cut as in $\mathrm{F}$.

NS, *,**: not significant and significant at $P \leq 0.05$ and $P \leq 0.01$, respectively. 
Table 5. Total dry matter yield $\left(\mathrm{g} \mathrm{m}^{-2}\right)$ for ten mixtures under different cutting managements in two localities.

\begin{tabular}{|c|c|c|}
\hline & \multicolumn{2}{|c|}{ Total dry matter yield $\left(\mathrm{g} \mathrm{m}^{-2}\right)$} \\
\hline & Cagliari & Foggia \\
\hline \multicolumn{3}{|c|}{ Cutting management ${ }^{\dagger}(\mathrm{C})$} \\
\hline $\mathrm{G}$ & $218.2 \mathrm{~d}$ & $348.4 \mathrm{~b}$ \\
\hline $\mathrm{EF}$ & $662.8 \mathrm{~b}$ & $333.5 \mathrm{~b}$ \\
\hline $\mathrm{F}$ & $787.1 \mathrm{a}$ & $415.7 \mathrm{a}$ \\
\hline GEF & $282.3 \mathrm{~cd}$ & - \\
\hline $\mathrm{GF}$ & $372.1 \mathrm{c}$ & - \\
\hline
\end{tabular}

$\begin{array}{ll}462.6 \mathrm{bcd} & 346.0 \mathrm{~cd} \\ 541.0 \mathrm{a} & 351.0 \mathrm{bcd} \\ 407.0 \mathrm{de} & 296.3 \mathrm{~d} \\ 420.4 \mathrm{cde} & 341.2 \mathrm{~cd} \\ 487.1 \mathrm{abc} & 332.0 \mathrm{~cd} \\ 486.4 \mathrm{abc} & 405.5 \mathrm{ab} \\ 498.0 \mathrm{ab} & 348.3 \mathrm{~cd} \\ 530.9 \mathrm{ab} & 431.3 \mathrm{a} \\ 422.9 \mathrm{cde} & 388.3 \mathrm{abc} \\ 388.7 \mathrm{e} & 418.8 \mathrm{a}\end{array}$

$\operatorname{LSD}_{(P \leq 0.05)}$

$\begin{array}{lrr}\mathrm{C} & 106.4 & 63.4 \\ \mathrm{M} & 72.7 & 56.7 \\ \mathrm{C} \times \mathrm{M} & 160.5 & 95.9\end{array}$

${ }^{\dagger}$ Cutting management: $\mathrm{G}=$ two simulated grazings; $\mathrm{EF}=$ one cut at early flowering; $F=$ one cut at full bloom; GEF $=$ as $\mathrm{G}$ and regrowth cut as in EF; GF = as $\mathrm{G}$ and regrowth cut as in $\mathrm{F}$.

Values within a column for each principal factor not followed by the same letter are significantly different at $P \leq 0.05$.

expected, a higher percentage contribution under treatments EF and F (51\% on average). At Foggia, grass dominance was a permanent feature of all treatments, and all the mixtures contained about $84 \%$ of grass.

However, when the composition of the mixtures was examined there were great differences in grass contribution to total production in both localities ranging from $16 \%$ (mixture 7 in GEF) to $70 \%$ (mixture n. 10 in GEF and GF) at Cagliari and from $38 \%$ (mixture 3 in EF) to $100 \%$ (mixtures 6, 8 and 10 in F) at Foggia (Figure 1). The percentage contribution of grass dry matter was significantly correlated with total dry matter production $\left(\mathrm{g} \mathrm{m}^{-2}\right)$ at Foggia $(\mathrm{r}=$ $0.54 * *, \mathrm{n}=30$ ) but not at Cagliari.

In all treatments a predominance of Italian ryegrass was found with respect to oats (mixtures $2,4,6,8$ and 10), probably due to a higher aggressiveness and earliness (particularly for cv. "Asso"). As a consequence, there were large effects of grass species on legume species par- ticularly in the clover or burr medic component.

There were few differences in percent contribution within each cutting treatment between crimson and squarrosum clovers with both oat (mixtures 1, 3 and 5) and Italian ryegrass (mixtures 2, 4 and 6) in each locality. Moreover, under treatment $\mathrm{G}$, the percentage contribution of berseem clover (mixtures 7 and 8) was superior (30\% on average) to those of other clovers and burr medic (17\% on average), both in mixture with oat and Italian ryegrass at Cagliari only.

The effect of the clover variety was not very pronounced (see mixtures 3 and 5). For Cagliari, the mixtures were characterized by a good proportion of legumes and grasses, associations 2 and 8 showing the highest total dry matter yield (average 541.0 and $530.9 \mathrm{~g} \mathrm{~m}^{-2}$ over treatment).

\section{Discussion}

Forage yields were affected by the climatic conditions occurring in the two localities during the experimental period. Thus, the higher rainfall and temperatures as well as a greater consistency recorded for these climatic parameters during the growing season probably promoted the growth of legume plants at Cagliari. Our results showed that mixtures were well established and botanical species were equally distributed in both localities. However, each association differently evolved at the two sites during the growing period.

It is well known that rapidly developing plant species ensure good establishment and early yield. However, another factor in determining the expected botanical composition of the forage mixtures is the seed ratio between components. As reported by Kessler and Lehmann (1998) in order to enable a weak competitor to become establish, the seeding rate of strong competitors has to be below their "critical seed density" (i.e. the threshold value of plant density to prevent intraspecific competition effects). Furthermore, the optimum seeding rate for the species included must consider both their specific "critical seed density" and their competing ability with other species. Corleto (1988) reported that in a Mediterranean environment the most aggressive grasses should represent 20$40 \%$ of the total weight of the mixture.

The ten legume-grass mixtures examined 
Table 6. Mean and standard deviation of each botanical component (\% on dry matter basis) over mixtures under different cutting managements in two localities.

Cutting

\begin{tabular}{|c|c|c|c|c|c|c|c|}
\hline \multirow{2}{*}{ management } & & & & & & & \\
\hline & 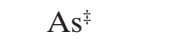 & $\mathrm{Lm}$ & $\mathrm{Ta}$ & $\mathrm{Ti}$ & Ts & $\mathrm{Mp}$ & Vs \\
\hline \multicolumn{8}{|l|}{ Cagliari } \\
\hline $\mathrm{G}^{\dagger}$ & $39.9 \pm 11.1$ & $57.6 \pm 11.8$ & $30.1 \pm 9.0$ & $18.6 \pm 8.1$ & $16.8 \pm 10.6$ & $7.9 \pm 8.1$ & $32.6 \pm 13.7$ \\
\hline $\mathrm{EF}$ & $41.8 \pm 11.8$ & $49.8 \pm 23.1$ & $8.3 \pm 4.4$ & $5.1 \pm 3.3$ & $5.5 \pm 5.7$ & $7.2 \pm 6.8$ & $47.9 \pm 17.4$ \\
\hline $\mathrm{F}$ & $35.6 \pm 8.7$ & $46.4 \pm 22.4$ & $6.2 \pm 3.7$ & $4.6 \pm 2.4$ & $6.3 \pm 3.9$ & $7.6 \pm 7.1$ & $53.1 \pm 16.7$ \\
\hline GEF & $26.5 \pm 13.1$ & $58.5 \pm 19.1$ & $17.9 \pm 9.3$ & $25.5 \pm 8.5$ & $24.4 \pm 14.4$ & $13.7 \pm 16.4$ & $36.1 \pm 21.0$ \\
\hline GF & $28.4 \pm 9.9$ & $61.4 \pm 16.9$ & $22.1 \pm 5.1$ & $31.8 \pm 13.0$ & $23.2 \pm 11.5$ & $16.4 \pm 15.9$ & $30.1 \pm 16.0$ \\
\hline $\operatorname{LSD}_{(P \leq 0.05)}$ & 6.9 & 10.6 & 6.2 & 5.6 & 9.8 & 7.5 & 6.6 \\
\hline \multicolumn{8}{|l|}{ Foggia } \\
\hline $\mathrm{G}$ & $65.7 \pm 9.5$ & $87.1 \pm 4.4$ & $13.6 \pm 9.8$ & $9.5 \pm 6.0$ & $9.7 \pm 6.3$ & $13.2 \pm 8.2$ & $12.5 \pm 7.5$ \\
\hline $\mathrm{EF}$ & $64.5 \pm 18.7$ & $96.3 \pm 5.4$ & $11.7 \pm 12.1$ & $25.7 \pm 24.8$ & $15.9 \pm 20.2$ & $15.2 \pm 10.4$ & $0.9 \pm 2.9$ \\
\hline $\mathrm{F}$ & $74.4 \pm 10.8$ & $98.6 \pm 2.0$ & $14.5 \pm 18.4$ & $16.0 \pm 14.6$ & $10.3 \pm 14.0$ & $9.9 \pm 11.6$ & $0.2 \pm 0.6$ \\
\hline $\operatorname{LSD}_{(P \leq 0.05)}$ & 8.1 & 2.6 & NS & 8.7 & NS & NS & 2.1 \\
\hline
\end{tabular}

Cutting management: $\mathrm{G}=$ two simulated grazings; $\mathrm{EF}=$ one cut at early flowering; $\mathrm{F}=$ one cut at full bloom; $\mathrm{GEF}=$ as $\mathrm{G}$ and regrowth cut as in $\mathrm{EF} ; \mathrm{GF}=$ as $\mathrm{G}$ and regrowth cut as in $\mathrm{F}$.

${ }^{*} \mathrm{As}=$ Avena sativa $; \mathrm{Lm}=$ Lolium multiflorum $; \mathrm{Ta}=$ Trifolium alexandrinum $; \mathrm{Ti}=$ Trifolium incarnatum $; \mathrm{Ts}=$ Trifolium squarrosum $; \mathrm{Mp}=$ Medicago polymorpha $; \mathrm{Vs}=$ Vicia sativa .

At each cutting management and locality, the botanical composition is given as average of mixtures containing each species.

produced the highest dry matter yield when a single cut was applied in spring (without grazing simulation - treatments $\mathrm{EF}$ and F) com- pared to fodder crops subjected to winter grazing simulation. These results are in agreement with those reported by Cazzato et al. (1999)

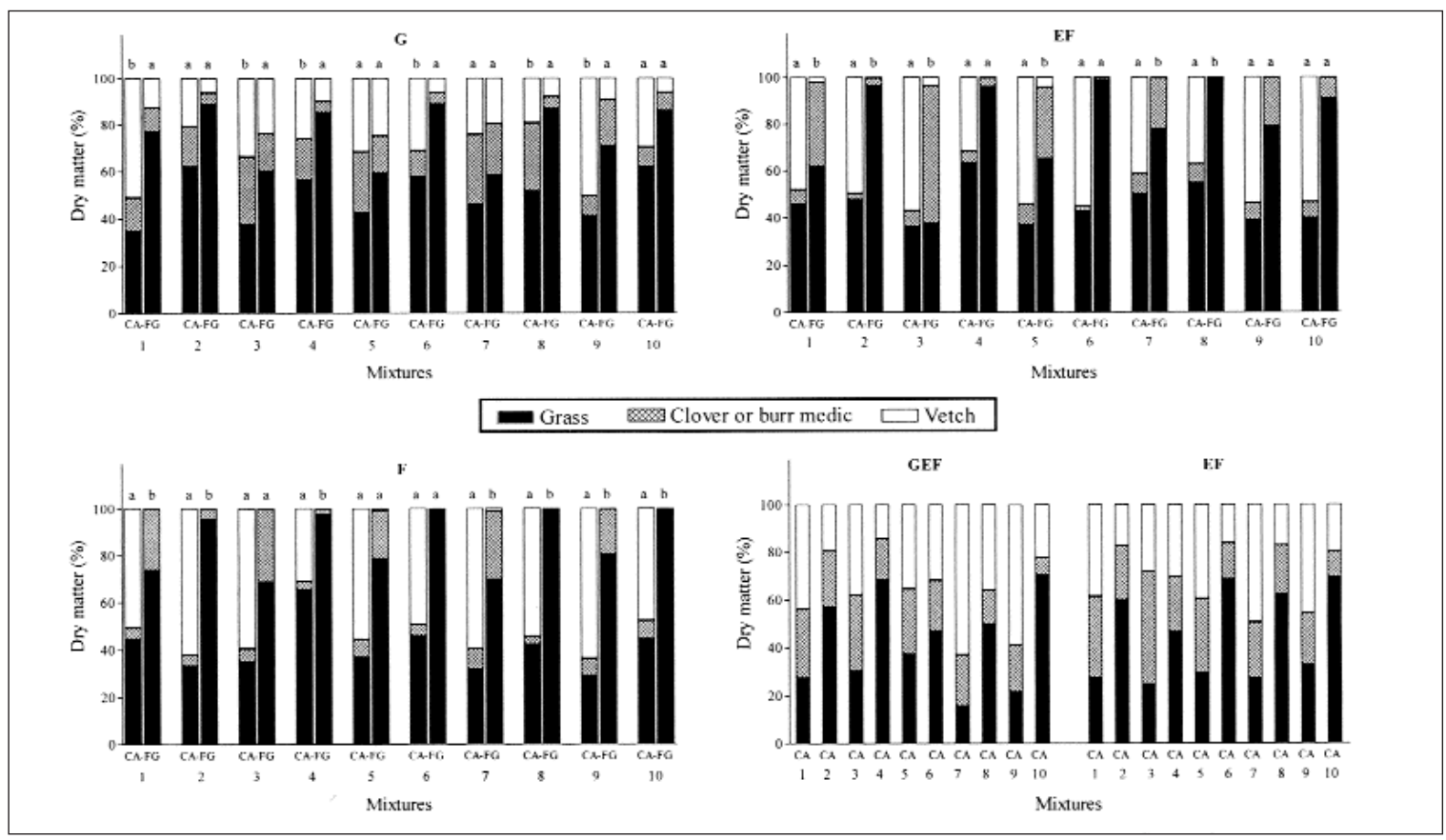

Figure 1. Percentage contribution of the species components to total dry matter production for ten grass-legume mixtures at five cutting managements in two localities. Cutting management: G, two simulated grazings; EF, one cut at early flowering; F, one cut at flowering; GEF, as G and regrowth cut as in EF; GF, as G and regrowth cut as in F. Locality: CA, Cagliari; FG, Foggia.

In each graph $\mathrm{h}$ istograms, within each mixture, not having the same letter are significantly different by $\mathrm{P} \leq 0.05$ for total dry matter $\left(\mathrm{g} \mathrm{m}^{-2}\right)$ trait. 
with two different fodder crop mixtures (crimson clover + common vetch + oat or Italian ryegrass) in two inland areas of southern Italy. However, under treatment $\mathrm{F}$, the high yield was due firstly to the contribution of grass and vetch at Cagliari and of grass only at Foggia. Here, the unfavourable winter conditions caused a considerable decrease of the vetch in the stand. According to Hill and Gleeson (1988), the most important factors affecting competition among establishing seedlings are the relative vigour of the seedlings and their densities. However, growth habit, pattern of plant development and response to the environment also has a significant effect.

Annual clovers are known to be weak competitors for resources compared with grasses, which have an erect growth, a greater biomass of thin roots and less specific climatic and nutritional requirements. Furthermore, as reported by Dunlop and Hart (1987), nitrogen application increased the competitiveness of grasses for light and nutrients and at the same time produced a reduction in nodulation and $\mathrm{N}$ fixation in legumes. Cazzato et al. (1999) reported that nitrogen fertilization applied in spring in forage mixtures produced a decrease in the occurrence of crimson clover and vetch and an increase in grass species. In our case, the effect of nitrogen being applied after cold damage suffered by plants probably produced the dominance of grass in all mixtures under treatments $\mathrm{EF}$ and $\mathrm{F}$ at Foggia. According to Cazzato et al. (1999), at Cagliari we recorded the lowest competitive ability of the clovers or burr medic when mixtures were not subjected to winter grazing, but a higher ability of regrowth under grazing conditions.

Thus, cutting management and weather conditions during growth had different effects on the development of legumes in association with graminaceous species. The potential benefits of legumes, namely $\mathrm{N}$ fixation, improving nutritional characteristics and intake, can be fully realized only if they are found in sufficient amounts in the sward (Thomson and Raymond, 1970). A legume content of 30 and $50 \%$ is the desired agronomic level. Hence, the fact that defoliation treatments alter the legume-grass balance is obviously of importance in this context.

Starting from the same mixture type, the proportion of grasses widely varied between the two locations, reaching $100 \%$ at Foggia. This indicates the difficulty in controlling forage com- position. In this respect, the performance of grass species, particularly Italian ryegrass, was crucial because under favourable development conditions they had the potential to outgrow and to suppress the other components. Martiniello (1999) reported that the proportion of legumes in binary mixtures depended on the graminaceous species used and that the lower legume percentages recorded in non-irrigated mixtures showed that clovers are less able to compete in water stress conditions than graminaceous species. Furthermore, compared to grasses, legumes are less aggressive and competitive, less shade tolerant, less productive and some of them are less resistant to grazing $(\mathrm{Pa}-$ panastasis and Papachristou, 2000).

Clear differences in the interaction between clover or burr medic and grass species depended on localities. At Foggia, interaction between these species appears to be based on competition effects: high grass yields occur with low clover yields and vice versa. However, at Cagliari, the relationship is more complex: high grass yields can be supported without reductions in clover yields. Our results did not indicate that there was major interaction between clover varieties. Generally, each clover variety responded in a similar way to their grass companion. At Cagliari, the mixtures consisting of Italian ryegrass, berseem or crimson clovers and vetch showed the highest adaptability to both cutting treatments.

\section{Conclusions}

The agronomic value of swards depends on their botanical composition, which is influenced by the seed ratio of the mixture and the management practice.

In an assessment programme of legumegrass associations, "cutting only" management has advantages in that it is an easily operated, low-cost system. However, such evaluation methods can prove unrealistic when the end-use is for grazing management. Clearly, the main attraction of these fodder crop mixtures is the increase in forage yield and higher feeding value, but for guaranteed successful use effective control of grass growth is essential.

The herbage quality of the mixture, meant both as variation of floristic composition and 
the relative chemical composition, is a function of each species and of the type of management. As reported by Castro et al. (2000) the substitution of the only one botanical component produced a significant variation in the most important chemical compounds of the mixture (for example: oat - vetch or wheat - vetch). Our results indicated that treatments imposed could have great effects on subsequent quality and quantity of the herbage available. Thus, the winter grazing simulation and combined cutting management (integrated grazing and cutting) provided a reasonably economical tools for assessing mixtures performances under diverse farming conditions. However, as a fraction of the plant population in swards of this experiment diminished over time, particularly at one site, the optimum of species present in these forage species associations have yet to be determined. Further experiments will also be necessary to study the mechanisms that affect the balanced presence of all species belonging to the mixture, and to assess the competitive relationships established between grass and legume plants.

\section{References}

Barnett F.L., Posler G.L. 1983. Performance of cool-season perennial grasses in pure stands and in mixtures with legumes. Agron. J., 75:582-586.

Blondel J., Aronson J. 1999. Biology and wildlife in the Mediterranean region. Oxford University Press, Oxford, UK.

Caballero R. 1993. An experts' survey on the role of forage legumes in arable cropping systems of the Mediterranean area. J. Sustainable Agriculture, 3, 3/4:133-154.

Castro M.P., Sau F., Piñeiro J. 2000. Effect of seeding rates of oats (Avena sativa L.), wheat (Triticum aestivum L.) and common vetch (Vicia sativa L.) on the yield, botanical composition and nutritive value of the mixture. In: Sulas L. (ed.): Proc. $10^{\text {th }}$ Meeting FAOCIHEAM Sub-Network on Mediterranean Pastures and Fodder Crops, 4-9 April, Sassari, Italy, 207-211.

Cazzato E., Laudadio V., Corleto A. 1999. Influenza delle modalità di utilizzazione e della concimazione azotata sulla produzione e la qualità di 2 erbai oligofiti autunno-primaverili. Riv. Agron., 33:250-256.

Corleto A. 1988. Gli erbai in Italia meridionale. In: Reda (ed.): Gli erbai: 99-109. Collana 1'Italia agricola.

Del Pozo A., Aronson J. 2000. Ecophysiology of annual legumes. In: Sulas L. (ed.): Proc. $10^{\text {th }}$ Meeting FAOCIHEAM Sub-Network on Mediterranean Pastures and Fodder Crops, 4-9 April, Sassari, Italy, 223-230.
Dobson J.W., Fisher C.D., Beaty E.R. 1976. Yield and persistence of several legumes grown with tall fescue. Agron. J., 68:123-125.

Dunlop J., Hart A.L. 1987. Mineral nutrition. In: Baker M.J. and Williams W.M. (eds.): White clover, 153-183. Cab International, UK.

Evans D.R., Williams T.A., Mason S.A. 1990. Contribution of white clover varieties to total sward production under typical farm management. Grass and Forage Sci., 45:129-134.

Hill M.J., Gleeson A.C. 1988. Competition among seedlings of phalaris, subterranean clover and white clover in diallel replacement series mixtures. Grass and Forage Sci., 43:411-420.

Jones T.A., Carlson I.T., Buxton D.R. 1988. Reed canarygrass binary mixtures with alfalfa and birdsfoot trefoil in comparison to monocultures. Agron. J., $80: 49-55$.

Kessler W., Lehmann J. 1998. Swiss grass-clover mixtures for leys. In: Boller B. and Stadelmann F.J. (eds.): Proc. $21^{\text {st }}$ Meeting of the Fodder Crops and Amenity Grasses Section of Eucarpia, 9-12 September, Kartause Ittingen, Switzerland, 79-82.

Martiniello P. 1999. Effects of irrigation and harvest management on dry-matter yield and seed yield of annual clovers grown in pure stand and in mixtures with graminaceous species in a Mediterranean environment. Grass and Forage Sci., 54:52-61.

McBratney J.M. 1981. Productivity of red clover grown alone and with companion grasses over a 4-year period. Grass and Forage Sci., 36:267-279.

McBratney J.M. 1984. Productivity of red clover grown alone and with companion grasses: further studies. Grass and Forage Sci., 39:167-175.

Papanastasis V.P., Mansat P. 1996. Grasslands and related forage resources in Mediterranean areas. In: Parente G., Frame J., Orsi S. (eds.): Proc. $16^{\text {th }}$ General Meeting of the European Grassland Federation, 1519 September, Grado-Gorizia, Italy, 47-57.

Papanastasis V.P., Papachristou T.G. 2000. Agronomic aspects of forage legumes: management and forage quality. In: Sulas L. (ed.): Proc. $10^{\text {th }}$ Meeting FAOCIHEAM Sub-Network on Mediterranean Pastures and Fodder Crops, 4-9 April, Sassari, Italy, 113-126.

Sheaffer C.C., Marten G.C., Rabas D.L. 1984. Influence of grass species on composition, yield, and quality of birdsfoot trefoil mixtures. Agron. J., 76:627-632.

Sitzia M., Ligios S., Fois N. 2000. Medicago polymorpha L. forage production and its quality when grazed by ewes. In: Sulas L. (ed.): Proc. 10 ${ }^{\text {th }}$ Meeting FAOCIHEAM Sub-Network on Mediterranean Pastures and Fodder Crops, 4-9 April, Sassari, Italy, 191-194.

Thomson D.J., Raymond W.F. 1970. White clover and animal production. Nutritional factors: a review. In: Lowe J. (ed.): White clover research, 277-284. British Grassland Society, Occasional Symposium, No. 6. 